\title{
ECONOMIC IMPLICATIONS OF INSUFFICIENT HEALTH LITERACY
}

Nikolina Dukića, Andrea Arbula Blecichb', Ljerka Cerovićc

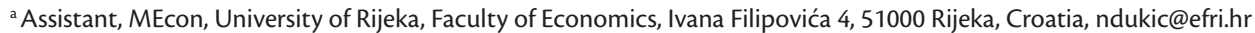
${ }^{b}$ Novice Researcher, MEcon, University of Rijeka, Faculty of Economics, Ivana Filipovića 4, 51000 Rijeka, Croatia, aarbula@ efri.hr

'Associate Professor, Ph.D, University of Rijeka, Faculty of Economics, Ivana Filipovića 4, 51000 Rijeka, Croatia, cerovic@ efri.hr

\section{ARTICLE INFO}

Keywords:

- health literacy

- information asymmetry

- public healthcare costs

- S-TOFHLA

\section{ABSTRACT}

The main goal of this paper is to elaborate the importance of health literacy in cost-effective utilization of health care services which influence the efficiency of the entire health care sector. In order to complement the theoretical framework of the economic implications and the circular influence of health literacy on the economy, an empirical analysis was carried out using S-TOFHLA. The results suggest that the patients' personal characteristics and the accessibility to health care services influence the level of health literacy which affects the health care costs.

Reference to this paper should be made as follows: Dukić N, Blecich A, Cerović Lj,. 2013. Economic implications of insufficent heakth literacy, Ekonomska istraživanja - Economic Research Special Issue 2013

This paper was created as part of the project of University of Rijeka, "Concepts and methods of cost and management accounting in the public sector of Croatia". 


\section{INTRODUCTION}

One of the main reasons for an inefficient health care $(\mathrm{HC})$ market is the lack of consumer (patient) sovereignty and its inability of making rational choices which cause difficulties in assessing the usefulness of HC services (Zweifel, Breyer and Kifmann, 1997) and increases the agency related costs in $\mathrm{HC}$. In the $\mathrm{HC}$ market there is knowledge and information asymmetry between users and providers of $\mathrm{HC}$, making the agency relationships very complex and, therefore, a very fertile research issue. Its importance has been emphasized since the 1970s as a part of broader orientation on the patients' skills and capabilities to meet the requirements of the modern society.

The problem of increasing expenditures and inefficient $\mathrm{HC}$ in Croatia imposes the need for continuous $\mathrm{HC}$ reforms. In order for the reforms to be efficient, it is essential to take the holistic approach to the HC system. Therefore, it is important to take the patients' side into perspective and to account for their health literacy $(\mathrm{HL})$ as "the personal, cognitive and social skills which determine the ability of individuals to gain access to, understand, and use information to promote and maintain good health" (Nutbeam, 2000). Hence, the main goal of this paper is to examine the factors influencing the populations' $\mathrm{HL}$ in order to better understand the economic effects of $\mathrm{HL}$ and the circular influence of $\mathrm{HL}$ on the economy.

To the best authors' knowledge, this research is the first on HL in Croatia. A comprehensive test for measuring the individual level of HL, S-TOFHLA was used and therefore translated into Croatian. Because of significant differences of language and HC system between USA and Croatia, the S-TOFHLA underwent some adjustments. In order to maintain the originality of the S-TOFHLA, experts in the fields of economics, medicine, language and sociology were consulted.

According to Fuchs (2000), the future of health economics relies on better understanding of economic behavior in $\mathrm{HC}$ and its usefulness regarding $\mathrm{HC}$ decision making. Respectfully, research on $\mathrm{HL}$, which undoubtedly generates numerous economic implications, complements the above mentioned fields of economic research.

Beside the introduction, this article has the following structure. Section II discusses about the agency costs that arise on the $\mathrm{HC}$ market as well as the economic effects of inadequate $\mathrm{HL}$. Section III brings the results and the major findings of the research and offers an empirical model for estimating $\mathrm{HL}$ from multiple variables. Section IV draws out the main conclusions of this research.

\section{AGENCY COSTS IN THE HEALTH CARE MARKET}

Perfect market mechanism represents the golden standard of a resource allocation which allows producers/service providers and consumers to operate freely and independently. However, $\mathrm{HC}$ is not a product/service to which the principles of purely economic goods can be applied. For this reason $\mathrm{HC}$ is a matter of public policy and administrative decisions.

One of the reasons for the existence of an inefficient HC market is the lack of consumer (patient) sovereignty. This refers to the patient's inability to make rational choices (Zweifel, Breyer and Kifmann, 1997). Lack of perfect information is not an exclusive characteristic of the HC market, but is also present in many other markets and is the reason for insufficient market transparency. The problem of patient's sovereignty is pronounced in the $\mathrm{HC}$ market because patients lack the ability to make rational choices and to evaluate $\mathrm{HC}$ services objectively. Also, the causality between treatment and health status may be affected by various biological processes, making an objective judgment of $\mathrm{HC}$ almost impossible. Finally, in the $\mathrm{HC}$ market there is knowledge 
and information asymmetry between users and providers of HC, making the patient-physician relationship very complex and a fertile research topic. The existence of agency relationships, the divergence between physicians and patients goals and the information asymmetry are causing agency costs (Jensen and Mackling, 1976) to the health service market.

One of the main reasons for the occurrence of agency problems in $\mathrm{HC}$ is that the patient does not have enough knowledge about the actions that the physician should take. This violates the basic principle of the agency theory according to which the principal (patient) knows exactly what actions the agent (physician) should take. This puts the agent into a monopoly position. Also, the patient's demand for HC depends both on his health state and the way the physician evaluates his health state regarding his medical knowledge. However, it is not rare that the patient or the third party (payer) cannot directly evaluate the usefulness of his advice (Cerović, Dukić and Horvat, 2012). Even if there is a possibility for the physician to be supervised by the patient, he cannot pass judgment on whether the physician's action is appropriate or not, while the health outcome itself is not a perfect function of the received $\mathrm{HC}$ due to many other factors that affect health.

Optimal consumption of $\mathrm{HC}$ means using $\mathrm{HC}$ effectively in a way that individuals could evaluate health within their utility function (Hurley, 2000). Patients know best how the improvement of their health status affects their well-being (utility level), while doctors have better information on alternative health interventions in treatment and prevention. Therefore, patients should be in the position of making informed decisions about $\mathrm{HC}$ utilization which, among other, requires an adequate level of $\mathrm{HL}$.

The term $\mathrm{HL}$ was firstly introduced as part of the research „Health Education as Social Policy" by the Johns Hopkins University in Baltimore (Simonds, 1974), while further interest in HL in USA (leading country in HL research and measurement) have arisen after the findings of the 1992 National Adult Literacy Survey (NALS). According to this survey, of 191 million adult Americans, 40-44 million were insufficiently functional health literate and another 53.5 million were marginally functional health literate (Kirsch et al., 1993). Since a significant percentage of the population has inadequate levels of $\mathrm{HL}$, the lack of $\mathrm{HL}$ is an important problem, also called "silent epidemic" (Perker et al., 2003). Inadequate HL is also a major generator of economic inefficiency in the HC system (Vernon et al., 2007). Some researchers even suggest that advancing HL may become a global challenge for the $21^{\text {st }}$ century (Nutbeam and Kickbusch, 2000).

\section{A. Health literacy and its economic implications}

The three most widely accepted areas of HL defined by Nutbeam (2000) include functional, interactive and critical HL. Functional literacy is the first area of HL and it refers to basic reading and writing skills that allow effective functioning in individual health domain (ability to read health information about health risks factors as well as ability of using the health services within the HC system). The second area of HL refers to interactive HL that involves use of more advanced skills like cognitive, literacy and social. These skills can be used in purpose of participation in different health activities, understanding different forms of health messages and application of health information in changing circumstances. The third area - critical HL encompasses even more advanced cognitive and social skills that are used for critical analysis of health information, improvement of individual and social capacity and understanding of political and economic dimensions of health.

$\mathrm{HL}$ is recognized as shared function of individual and social factors, and most conceptual models have identified the individual as well as the system-level factors that influence a person's 
level of HL. Lee, Arozullah, and Cho (2004) suggest that social support may moderate the impact of low HL on health status and health service use.

The principal goal of public health policy is the improvement of population health by means of available resources with maximum health outcomes, and, beside health implications, insufficient $\mathrm{HL}$ also causes economic implications, as shown in figure 1.

FIGURE 1 - CIRCULAR INFLUENCE OF HEALTH LITERACY

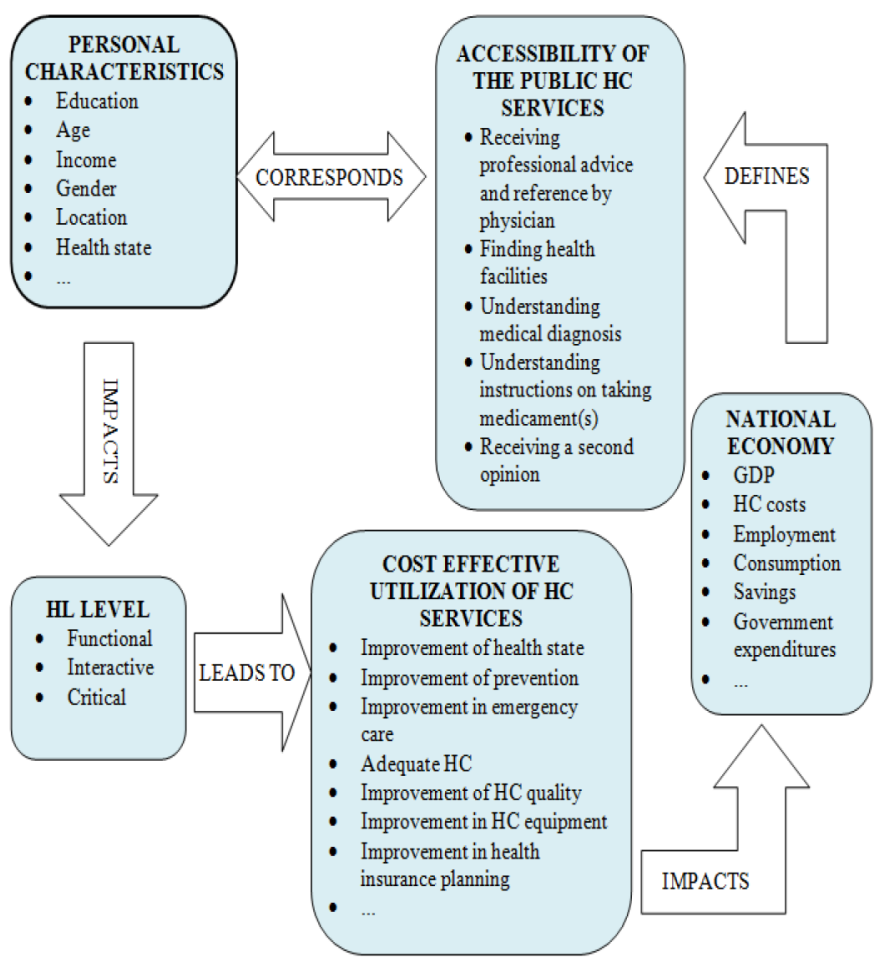

\section{Source: Author}

Many HC systems are characterized by increasing health spending and a sort of $\mathrm{HC}$ crisis, which is not caused solely due to the lack of money (Pelletier et al., 2009), but also due to the non-compliance of $\mathrm{HC}$ spending, the fragmentation of $\mathrm{HC}$ services, the non-existence of continuous $\mathrm{HC}$ and the inadequate funding of cost-effective interventions. Health policies designed to improve $\mathrm{HL}$ among the population have major influence on reducing health care costs and utilization of preventive activities (Vernon et al., 2007).

Observed from an economic standpoint, the demand for HC derives from the demand for good health (Grossman, 2000) and by investing in health (health capital) an individual can increase its level of utility because of the improved health. Conceptually, HL can be observed as one of the preconditions for achieving good health while the individual $\mathrm{HL}$ level affects the efficiency of the HC system (Howard, Gazmararian and Parker, 2005; Weiss and Palmer 2004).

Poor health affects the economy through spending and savings (capital formation), as well as the level of education (Suhrcke et al., 2006). Reduced household consumption and the level of 
education, due to illness, have a negative impact on gross domestic product, while at the same time $\mathrm{HC}$ expenditures across Europe are taking an increasingly large share in the public and private consumption. Empirical research at the micro level shows that chronic diseases reduce wages, earnings, labor force participation and productivity, affecting also early retirement, disability benefits and high rate of employee turnover (Suhrcke et al., 2006).

Inadequate communication, insufficient information and instructions which patients hardly understand cause barriers while using $\mathrm{HC}$ and inefficiency in health capital production.

\section{B. Health literacy empirical research}

An empirical research indicates that insufficient $\mathrm{HL}$ can cause inefficiency in the HC system. Insufficient HL is linked to poor health status (Baker et al. 2007) and scarce use of preventive HC (Nielsen-Bohlman, Panzer and Kindig, 2004; Pignone et al., 2005). It is important to emphasize that in some cases (Nutbeam, 2000) HL is viewed as a key outcome of health promotion/prevention of the disease. They cover the aspects that increase HL such as the improvement of knowledge of health, the impact on changing attitudes and the development of certain skills. Furthermore, insufficient HL results with increasing hospitalization (Baker et al. 1998, 2002; Schillinger et al., 2002) and health system costs (Vernon et al., 2007; Friedland, 2002; Weiss and Palmer, 2004).

In recent researches, the influence of patients' HL level on the quality of their HC was investigated. Most of them studied health or social outcomes of poor HL (Gazmararian et al., 1999; Adams et al., 2013). On the other hand, the economic implications were neglected. A first systematic review of the economic implications of low $\mathrm{HL}$ is made by Eichler, Wieser and Brügger (2009). They emphasize low $\mathrm{HL}$ as a problem that can create substantial costs in the HC system (per year, on the system level: $3-5 \%$ of the total cost of HC and on the patient level: \$143-7798 per person). Adequate $\mathrm{HL}$ can help patients to reach good health level without creating additional unnecessary costs. Weiss and Palmer (2004), Friedland (1998, 2002), Vernon et al. (2007) studied the relationship between $\mathrm{HC}$ costs and insufficient $\mathrm{HL}$ and proved that the latter generates negative economic consequences through higher $\mathrm{HC}$ costs. Their research provided a quantitative estimation of additional costs incurred due to low HL. Weiss $(2003,2007)$ pointed out that insufficient $\mathrm{HL}$ creates great impact on the American $\mathrm{HC}$ system by causing huge cost burdens. Their research indicates that people with low HL generate more than four times higher costs than people with high HL. Research studying the impact of limited $\mathrm{HL}$ on costs have been made on the patient level (Howard, Gazmararian and Parker, 2005; Weiss and Palmer 2004; McCormack et. al., 2010) and on the system level (Friedland 1998; Vernon et al., 2007). They concluded that low HL leads to higher costs at the patients' level as well as at the HC system level.

Another type of research tries to determine how $\mathrm{HL}$ can be improved and which variables affect HL. Studies have shown that HL is extremely low among elder persons and that they have problems using and understanding information related to their health condition (Kirsch et al., 1993; Baker et al., 2007; Weiss, Reed and Kligman, 1995; Williams et al., 2002; Kutner et al., 2005; Safeer and Keenan 2005; Sudore et al., 2006). In some researches (National Center for Education Statistics, 2006; Weiss, Reed and Kligman, 1995) the level of income is also related to the level of $\mathrm{HL}$. People with low income and living below the poverty level showed lower HL than people living above the poverty level. Many studies found that there is a relation between gender and $\mathrm{HL}$ - women had higher HL than men (Sudore et al., 2006). Taking into account the geographical element, research showed that $\mathrm{HL}$ is lower in rural areas than in urban areas (Zahnd, Scaife and Francis, 2009) as well as among people who suffer from chronic illness (Schillinger et al., 2002). 
In the report Healthy People (2010) of the US Department of Health and Human Services, the connections between poor education, low literacy, poor health and early death were emphasized. Education, health and $\mathrm{HL}$ are interlaced among themselves. Higher levels of education might be promoting better HL and health knowledge (Mirowsky, Ross, 1998; Ross, Mirowsky, 1999). Education is also an important variable in $\mathrm{HL}$ cost containment because educated individuals will be able to better understand the relevant information which would help them to make better health decisions (Kirsch et al., 1993; Baker, 2006; McCormack et al., 2010).

In 2012, an important research on HL was carried out in Europe. The European Health Literacy Survey compared HL in selected eight EU member states by measuring "how people access, understand, appraise and apply information to make decisions in terms of HC, disease prevention and health promotion". The research identified and studied the impact of five significant and important social determinants listed in descending order by importance: financial deprivation, self-assessed social status, level of education, age, and gender. Although these selected variables showed significance, their impact varies from country to country, the results indicated higher average HL among young people, people with low financial deprivation, higher self-assessed social status and higher levels of education, and also in woman. The results implied that almost $50 \%$ of the people are at the risk of inadequate $\mathrm{HL}$ which is especially pronounced in certain groups where the risk exceeds $60 \%$. However, variable significance varies depending on the country, so it is advisable to expand the research to other European countries. (HLS - EU consortium, 2012).

\section{Health literacy tests}

One of the most frequently used comprehensive tests to measure the individual level of $\mathrm{HL}$ is the Test of Functional Health Literacy in Adults (TOFHLA). Following the continuous need for shorter tests, a shorter version of TOFHLA was developed - the S-TOFHLA (Baker et al., 1999). The latter instrument is used in this research because, despite shortness, it provides a complete assessment of functional $\mathrm{HL}$ as it was proved by numerous empirical researches. Following the number of points (from 0 to 100) achieved on the S-TOFHLA test, respondents are divided into three levels of HL: inadequate (0-53 points), marginal (54-66 points) and adequate (67-100 points). S-TOFHLA was originally developed in the USA and translated into a limited number of different languages. Therefore, for the purpose of this research, S-TOFHLA was translated into Croatian. Because of certain differences of language and HC systems between USA and Croatia, and upon consultations with experts in the fields of economics, medicine, language and sociology, the S-TOFHLA test underwent some adjustments.

\section{RESEARCH RESULTS AND DISCUSSION}

The S-TOFHLA questionnaire was distributed between two locations of the Clinical Hospital Centre Rijeka - Rijeka and Sušak, Croatia (520 respondents). The survey was conducted during March and April 2013. Individuals under 18 of age or lacking cooperation or being too ill to participate were excluded from the evaluation. Respondent characteristics and descriptive statistics based on S-TOFHLA are given in table 1. 
TABLE 1 - RESPONDENT CHARACTERISTICS AND S-TOFHLA DESCRIPTIVE STATISTICS

\begin{tabular}{|c|c|c|c|}
\hline & \multirow{2}{*}{$n(\%)$} & \multicolumn{2}{|c|}{ S-TOFHLA } \\
\hline & & Mean & St. dev. \\
\hline \multicolumn{4}{|l|}{ Gender } \\
\hline Male & $203(39.0)$ & 75.78 & 25.023 \\
\hline Female & $317(61.0)$ & 82.32 & 18.988 \\
\hline \multicolumn{4}{|l|}{ Age, categories } \\
\hline Below 45 & $246(47.3)$ & 86.88 & 11.831 \\
\hline 45-64 & $216(41,5)$ & 78.86 & 22.182 \\
\hline 65 and above & $58(11,2)$ & 52.91 & 29.964 \\
\hline \multicolumn{4}{|l|}{ Education level } \\
\hline Primary and without education & $46(8.8)$ & 52.93 & 29.932 \\
\hline Secondary education & $287(55,2)$ & 79.39 & 20.196 \\
\hline Tertiary education & $187(36.0)$ & 86.91 & 15.729 \\
\hline \multicolumn{4}{|l|}{ Place of residence } \\
\hline City and its broader surroundings & $459(88,3)$ & 80.44 & 21.701 \\
\hline Rural areas and islands & $61(11,7)$ & 74.61 & 21.670 \\
\hline \multicolumn{4}{|l|}{ Net income } \\
\hline No net income (0) & $67(12,9)$ & 85.21 & 11.838 \\
\hline$<2200$ HRK & $78(15.0)$ & 69.72 & 24.877 \\
\hline $2201-3600 \mathrm{HRK}$ & 102(19.6) & 69.05 & 27.697 \\
\hline $3601-8800 \mathrm{HRK}$ & $226(43.5)$ & 85.25 & 16.718 \\
\hline $8801-10800$ HRK & $28(5.4)$ & 90.07 & 17.782 \\
\hline > 10800 HRK & $16(3.1)$ & 78.81 & 22.950 \\
\hline \multicolumn{4}{|l|}{ Chronic illness } \\
\hline Yes & 153(29.4) & 70.25 & 27.183 \\
\hline No & $354(68.1)$ & 84.15 & 17.087 \\
\hline
\end{tabular}

Source: Research results

The overall $\mathrm{HL}$ results showed that $82.4 \%$ of the respondents have adequate level of $\mathrm{HL}$, $3.6 \%$ have marginal level of $\mathrm{HL}$ and $14 \%$ have inadequate level of $\mathrm{HL}$. Keeping in mind that the Primorsko-Goranska County and especially the City of Rijeka have leading socio-economic and labor market indicators (ASOO, 2011) in Croatia, it can be argued that the score limits for the categories of HL might not be too appropriate for the surveyed location. Therefore, statistical tests were carried out and the results were reported on interval (test result) scale rather than on nominal scale (three HL categories). From the point of statistical testing, the interval scale was justified 
by the use one-way ANOVA tests which are more robust than the Kruskal-Wallis (K-W) tests when heteroscedasticity is present in the data.

As pointed out within the research objectives, several (patients' personal, socio-economic, socio-demographic) factors (age, education, net income, employment, location of residence, gender, chronic illness) have been taken into account and their relationships with $\mathrm{HL}$ level were empirically tested. To establish which personal, socio-economic and socio-demographic characteristics influence the level of HL series one-way ANOVA tests were performed. As overall HL test results data represent a non-normal distribution with negatively skewed data $(-1.835$, Std. Error .107), reflected logarithmic transformation of the data was conducted which led to more normally distributed data with skewness lower than $1(-0.474$, Std. Error .107) upon which it was possible to utilize the robust ANOVA testing. Another argument in favor of reflected transformation of the data is that the factors' group variances were less different from each other.

The influence of age was tested after respondents have been divided into three groups (respondents under 45 years of age, between 45 and 64 years and above 65 years of age). A oneway ANOVA was used to test for $\mathrm{HL}$ test results differences among three different age groups. $\mathrm{HL}$ test results differed significantly across the three age groups $\left[F(2,517)=41.468, p=.000, R^{2}=.138\right]$. As the homogeneity of variance, assessed by Levene's Test for Equality of Variances, was violated, a Welch's $t$ test which does not assume equal variances was carried out. Significant effect for age groups $[t(176)=60.153, p=.000]$ was fund. Post hoc comparison using the Games-Howell test indicated that the mean score between all age groups ware significantly different at $\mathrm{p}<.05$ form each other. $\mathrm{HL}$ tests means $\left(\mathrm{M}_{1}=86.88,95 \% \mathrm{Cl}[85.39,88.36] ; \mathrm{M}_{2}=78.86,95 \% \mathrm{Cl}[75.88,81.83]\right.$; $\left.M_{3}=52.91,95 \% \mathrm{Cl}[45.04,60.79]\right)$ indicate that $\mathrm{HL}$ test results decrease with age.

Because heteroscedasticity was present in the data as well as was substantial difference in sample size of tree age categories $\left(n_{1}=248 ; n_{2}=216 ; n_{3}=58\right)$ data were randomly resampled into a three categories of $n=58$ in order to check the robustness of the results. Equalizing the sample size have assured the homogeneity of variance, assessed by Levene's Test for Equality of Variances at $p>.05$, and made the ANOVA procedure more robust $[F(2,171)=41.468, p=.000]$. However, Tukey post-hoc comparisons of the respondents under 45 years of age and respondents between 45 and 64 years of age were not statistically significant at $p<.05$. This means that $\mathrm{HL}$ test results are statistically different only between respondents younger than 45 and older than 65 years of age at $\mathrm{p}<.05$.

Further on, one-way ANOVA was used to test for HL test results differences among three different levels of education - "primary education or less", "secondary education" and "tertiary education". There was a significant effect of level of education on HL test results after ANOVA test was performed $\left[F(2,517)=43.369, p=.000, R^{2}=.144\right]$ even after assumption of the unequal variance using the Welch's $t$ test $(t(129)=47.364, p=.000)$. Additional post hoc Games-Howell tests with no equal variance assumed was performed indicating that the test results differ significantly among all levels of education with $\mathrm{p}<.05$. It can be concluded that the level of $\mathrm{HL}$ is increasing with the level of education $\left(M_{1}=52.93,95 \% \mathrm{Cl}[44.05,61.82] ; M_{2}=79.39,95 \% \mathrm{Cl}[77.05,81.75]\right.$; $M_{3}=86.91,95 \% \mathrm{Cl}[84.65,89.18]$ ) which supports previous empirical research results (Baker, 2006; McCormack et. al. 2010).

Again, like in the case of age, heteroscedasticity was present in the data as well as a substantial difference in sample size of three different levels of education $\left(n_{1}=46 ; n_{2}=287 ; n_{3}=187\right)$. Data were randomly resampled into a three categories of $n=46$ in order to check the robustness of the statistical test results. Only difference from the previous unequal sample size testing was 
that post hoc Games-Howell test did not find significant difference between respondents with "secondary education" and respondents with "tertiary education" at $\mathrm{p}<.05$.

After taking a Welch's $t$ test $\left(t(93)=17.220, p=.000, R^{2}=.142\right)$, analysis showed that $\mathrm{HL}$ test results differ significantly among different levels of monthly net income. The monthly net income was divided into five interval levels ( 1 - lowest; 5 - highest) with addition of respondents without net income. Additional Games-Howell post-hoc testing explained the differences in HL results by the different income level groups. Interestingly, respondents without net income had grater mean $(M=85.21,95 \% \mathrm{Cl}[82.32,88.10])$ than respondents from the first income level group ( $M$ $=69.72,95 \% \mathrm{Cl}[64.11,75.33])$ at $\mathrm{p}<.05$. An explanation can be found in the present economic crisis which led to a high unemployment rate among young educated people. Also, the first income level group mostly includes elderly respondents earning low pensions. First group also showed to be significantly different than the third $(M=85.25,95 \% \mathrm{Cl}[83.06,87.44])$ and the fourth group $(M=90.07,95 \% \mathrm{Cl}[83.18,96.97])$ at $\mathrm{p}<.05$. The second income level group $(M=69.05,95 \% \mathrm{Cl}$ $[63.61,74.49])$ was found to be statistically different from the third and the fourth income group as well as from the respondents without net income. Statistical analysis did not confirm statistically significant difference between the fourth and the fifth $(\mathrm{M}=78.81,95 \% \mathrm{Cl}[66.58,91.04])$ as well as between the respondents without net income and the fifth income level groups at $p<.05$. $\mathrm{HL}$ test means for different income levels are given in graph 1.

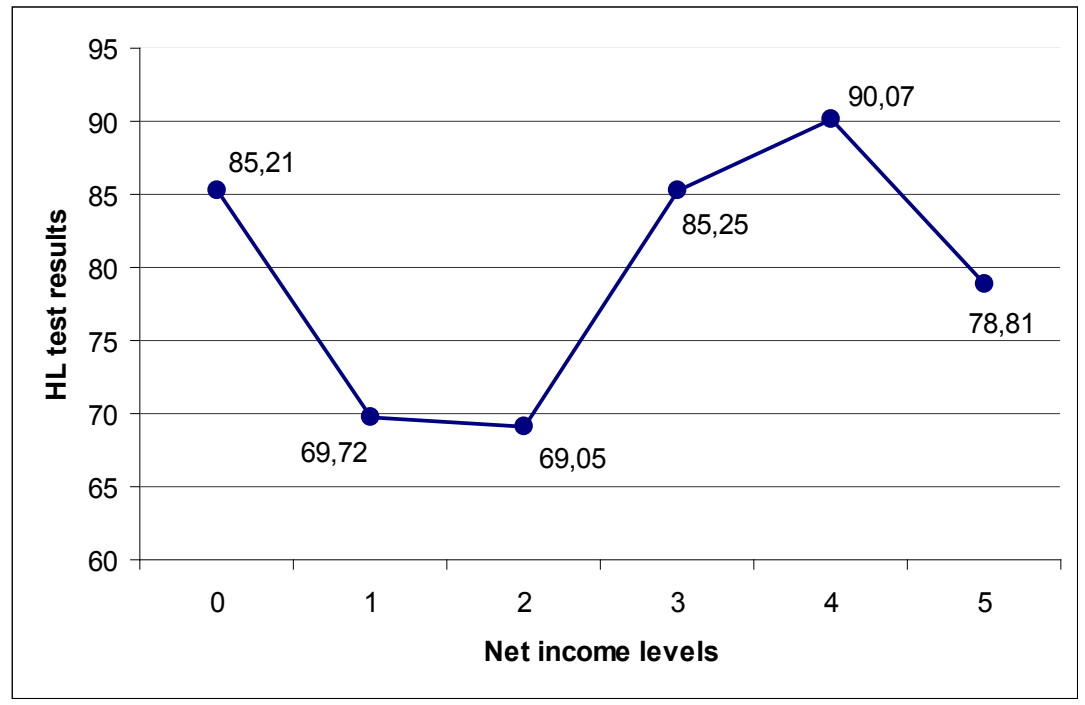

\section{GRAPH 1 - HL TEST MEANS FOR DIFFERENT INCOME LEVELS}

\section{Source: Author's calculation}

With respect to the location of residence, respondents were divided into two groups (respondents from the City of Rijeka and its broader surroundings and those from rural areas and islands). Homogeneity of variance, assessed by Levene's Test for Equality of Variances, was not violated at $p>.05$ and the ANOVA test indicated that the HL test results differ significantly by the location of residence $[F(1,518)=8.358, p=.004]$. The group means $\left(M_{1}=80.44 ; M_{2}=74.61\right)$ indicate that respondents from the City of Rijeka and its broader surroundings have better $\mathrm{HL}$ than respondents from rural areas and islands. These findings are in accordance with previous empirical research (Zahnd, Scaife and Francis, 2009). 
Also, the ANOVA test indicates that the variability in $\mathrm{HL}$ test results can be explained by gender $[F(1,518)=9.328, p=.002]$ which are slightly better for females $(M=82.31,95 \% \mathrm{Cl}[80.21,84.40])$ than males $(M=75.78,95 \% \mathrm{Cl}[72.32,79.24])$.

Welch's $t$ test results $[t(253)=23.712, p=.000]$ confirmed that the $\mathrm{HL}$ test results are significantly different between respondents with and without chronic illness, indicating that respondents without chronic illness achieve better results $(M=84.15,95 \% \mathrm{Cl}[82.36,85.94])$ than respondents with chronic illness $(M=70.25,95 \% \mathrm{Cl}[65.91,74.60])$.

After the relationships between $\mathrm{HL}$ results and patients' personal, socio-economic and socio-demographic variables were tested, the research goal (supported by previous empirical research and theoretical findings) was to determine if there is a relationship between level of $\mathrm{HL}$ and $\mathrm{HC}$ system characteristics (accessibility of the public HC services). Therefore, five steps were set to measure the level of easiness in:

1. receiving professional advice and reference by physician (general practitioner GP) (T1);

2. finding health facilities (T2);

3. understanding medical diagnosis (T3);

4. understanding instructions on taking medicament(s) (T4);

5. receiving second opinion from another physician (T5).

Some empirical findings suggest that reliable access to $\mathrm{HC}$ is significantly associated with level of HL (Vernon et al., 2007). The accessibility of public HC services is not only determined by personal characteristics, but also by characteristics of the HC system (Figure 1).

One-way ANOVA tests were conducted to determine if different levels (Lickert scale measure) of patients' perception of accessibility of the public HC services (T1-T5) could explain the variability of the HL test results. Statistical findings are given in table 2.

\section{TABLE 2 - ANOVA RESULTS FOR THE PERCEPTION OF ACCESSIBILITY AND THE HL TEST} RESULTS

\begin{tabular}{ccl}
\hline \hline Variable & ANOVA $F$ & P value \\
\hline \hline $\mathrm{T} 1$ & $\mathrm{~F}(4,500)=2.814$ & $\mathrm{p}=.025$ \\
$\mathrm{~T} 2$ & $\mathrm{~F}(4,489)=2.020$ & $\mathrm{p}=.090$ \\
$\mathrm{~T} 3$ & $\mathrm{~F}(4,488)=2.030$ & $\mathrm{p}=.085$ \\
$\mathrm{~T} 4$ & $\mathrm{~F}(4,493)=4.485$ & $\mathrm{p}=.001$ \\
$\mathrm{~T} 5$ & $\mathrm{~F}(4,488)=2.020$ & $\mathrm{p}=.000$ \\
\hline \hline
\end{tabular}

Source: Research results

Because all the variables (T1-T5) had $\mathrm{p}<.05$ on Levene's Test for Equality of Variances, the results of ANOVA F tests are presented in the above table. There was a significant effect of T1, T4 and $\mathrm{T} 5$ on the HL test results at the $\mathrm{p}<.05$. However, post hoc comparison using the Tukey's test indicated that all mean scores for different levels of $\mathrm{T} 1$ were not significantly different from each other at $p<.05$. Also, for variable T5 Tukey's test indicated that significant difference could only be found between the first $(M=73.90,95 \% \mathrm{Cl}[66.6,81.19])$ and the second $(M=85.82,95 \% \mathrm{Cl}[82.22$, 89.42]) level of T5. But more importantly, the test means did not indicate any constant directions. 
Post hoc comparison using Tukey's test suggested that significant difference can be found between the first $(M=54.17,95 \% \mathrm{Cl}[34.07,74.07])$ and the fourth $(M=82.76,95 \% \mathrm{Cl}[80.26,85.25])$ Lickert scale level as well as between the first and the fifth $(M=75.78,95 \% \mathrm{Cl}[72.32,79.24])$ level of T 4 at $\mathrm{p}<.05$. The means for T4 are given in graph 2.

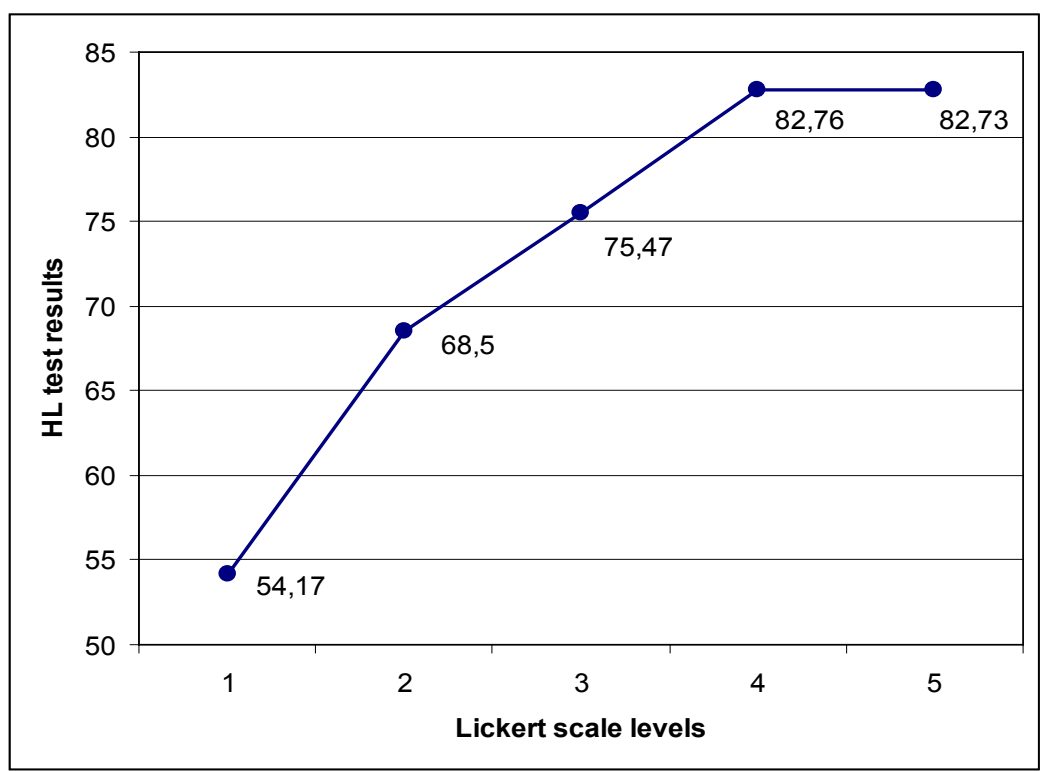

\section{GRAPH 2 - HL TEST MEANS FOR DIFFERENT LEVELS OF UNDERSTANDING INSTRUCTIONS ON TAKING MEDICAMENT(S) (T4)}

\section{Source: Author's calculation}

These findings can logically be interpreted when observed in the context of the Croatian socio-economic conditions and the HC system. Namely, when observing the level means of T5 (receiving a second opinion from another physician) and their changing direction, the explanation can be found in varying physicians' willingness to refer patients for a second opinion and also in the patients' scarce knowledge of their rights. The most interesting and the most economically valid results here refer to the suggestion that the variability in $\mathrm{HL}$ test results can be associated with the respondents' perceived easiness in understanding instructions on taking medicament(s).

Furthermore binary logistic regression model was used to investigate the effect of the above mentioned variables on the probability of achieving adequate level of HL. Assuming that variables have independent influence on $\mathrm{HL}$ test results, the following model was estimated.

$$
\begin{gathered}
\mathrm{Y}=\beta_{0}+\beta_{1} \mathrm{AGE}+\beta_{2} \text { FEMALE }+\beta_{3} \text { SEC.EDU }+\beta_{4} \text { TERT.EDU }+\beta_{5} \mathrm{RURAR}+\beta_{6} \mathrm{NET} 2+\beta_{7} \mathrm{NET} 3+ \\
\beta_{8} \mathrm{NET} 4+\beta_{9} \mathrm{NET} 5+\beta_{10} \mathrm{~T} 4+\beta_{11} \text { T5 }
\end{gathered}
$$

Where $\mathrm{Y}$ is the probability of adequate HL test results and variables AGE, T4 and T5 represent continuous variables opposed to gender, level of education, place of residence and net monthly income that are categorical variables with categories male, primary education, city and surroundings and the first net income level being reference cases respectively. 
After conducting a binary logistic regression estimated model is given by the following equation.

$$
\begin{gathered}
\mathrm{Y}=1,604+.072 \mathrm{AGE}+.670 \text { FEMALE }+1.217 \text { SEC.EDU }+1.341 \text { TERT.EDU }-1,193 \text { RURAR + } \\
1.203 \text { NET3 }+2.22 \text { NET } 4+.494 \text { T } 4-.329 \text { T5 }
\end{gathered}
$$

Hosmer and Lemeshow statistics has significance at $p=.737$ which means that it is not statistically significant and therefore the model presents a good fit. All the signs have the expected values according to the previous ANOVA statistics. In short, OR values indicate that the probability of adequate HL measured by S-TOFHLA was significantly higher among younger respondents, females, respondents having at least secondary education, respondents earning more than 3.600 HRK a month and respondents who have better understanding in taking medicaments. The highest influence, with regard to baseline categories, can be found in the variables "level of education" and "net income". Controlling for other variables, the model indicates that respondents with secondary and tertiary education are almost 4 times more likely to have adequate $\mathrm{HL}$ test results than respondents with primary education. Also, it is indicative that, controlling for other variables, respondents with a monthly net income over 3.600 HRK are 3.3 up to 9.3 times more likely to have adequate $\mathrm{HL}$ test results than respondents earning less than $2.200 \mathrm{HRK}$ monthly. Odds ratios (OR) are given in table 3.

TABLE 3 - ODDS RATIOS OF THE FACTORS ASSOCIATED WITH HL

\begin{tabular}{cccc}
\hline Variable & OR & $95 \%$ I & $\boldsymbol{p}$ \\
\hline \hline AGE & 0.931 & $0.908-0.954$ & 0.000 \\
FEMALE & 1.954 & $1.046-3.650$ & 0.036 \\
SEC.EDU & 3.378 & $1.369-8.337$ & 0.008 \\
TERT.EDU & 3.822 & $1.306-11.185$ & 0.014 \\
RURAR & 0.302 & $0.125-.0 .733$ & 0.008 \\
NET3 & 3.331 & $1.429-7.768$ & 0.005 \\
NET4 & 9.292 & $1.012-85.278$ & 0.049 \\
T4 & 1.639 & $1.133-2.373$ & 0.009 \\
T5 & 0.719 & $0.547-0.956$ & 0.018 \\
\hline \hline
\end{tabular}

Source: Research results

Finally, it was tested if the HL level could explain the differences in the perceived level of easiness of patients' orientation within the HC system (given by abovementioned 5 steps) which play important role in efficient and effective $\mathrm{HC}$ utilization. For this purpose nonparametric equivalent of one-way ANOVA - which allows for the comparison of more than two independent groups - the Kruskal-Wallis (K-W) test was used.

The K-W test showed that the three levels of $\mathrm{HL}$ (adequate, marginal and inadequate) could explain the differences in the variance of understanding instructions on taking medicament(s) T4 $(H(2)=6.495, p=.039)$. Levene's test of homogeneity of variance at $p=.585$ justified the use of $\mathrm{K}-\mathrm{W}$ test. These statistical findings confirm the existence of a relationship between level of $\mathrm{HL}$ and medicaments costs, which comprise a significant share in the public HC spending which confirm 
the previous research on the influence of low levels of $\mathrm{HL}$ on the increasing costs of medical care (Vernon et al., 2007; Weiss and Palmer, 2004; Friedland, 2002).

In Croatia (HZZO, 2013), the costs of the HC system have increased by more than 5\% in 2012 relatively to the previous year's costs. The total costs of medicaments amount to about $1.5 \%$ of the GDP and are constantly increasing through the years. Compared to 2011, medicaments on prescription have increased by more than $9 \%$ in 2012 and their share in the total costs of the HC structure is $18.22 \%$. Particularly expensive medicaments increased by more than $7 \%$ in 2012 with respect to the previous year and they represent $3.13 \%$ of the total costs of the HC structure. Most of these costs are subsidized by the public $\mathrm{HC}$ system and they represent a significant burden to the public spending. Therefore, a rational and efficient use of medicaments is crucial in order to reduce the costs and to redirect the excessive funds into more needful domains which are very important in the context of aging population and increasing prevalence of chronic illness. Additionally, post-hoc testing confirmed that the mean ranks of the $\mathrm{T} 4$ are significantly different from each other only between the categories of adequate $\mathrm{HL}(\mathrm{H}(2)=4.875, \mathrm{p}=.027)$ and inadequate $\mathrm{HL}(\mathrm{H}(2)=4.848, \mathrm{p}=.028)$. $\mathrm{HL}$ test means indicates that respondents with adequate level of $\mathrm{HL}(\mathrm{M}$ $=4.32,95 \% \mathrm{Cl}[4.25,4.39])$ have better understanding of instructions on taking medicaments than respondents with inadequate level of $\mathrm{HL}(\mathrm{M}=3.93,95 \% \mathrm{Cl}[72.32,79.24])$.

\section{CONCLUSION}

Inadequate $\mathrm{HL}$ is shown to be one of the main cost generators within national HC systems. A lot of researches have emphasized the influence of $\mathrm{HL}$ on health related issues with less attention given to the economic effects. The contribution of this paper, besides the empirical research, is in the explanation of the connection between agency costs in $\mathrm{HC}$ with inadequate $\mathrm{HL}$. In the $\mathrm{HC}$ market there is prominent agency problem due to information asymmetry between users and providers of $\mathrm{HC}$ which is accentuated by the inadequate level of $\mathrm{HL}$. Patients should be adequately informed and should possess skills and abilities to understand and process given information in order to make appropriate and efficient utilization of $\mathrm{HC}$ services.

$\mathrm{HC}$ is not a purely economic good and it is a matter of public policy and administrative decision making. Governments should be familiar with the factors that influence the population level of HL and therefore the research on $\mathrm{HL}$ is significant for the HC policy. Since a similar research has not been carried out previously in Croatia, this research fills the gaps of an inadequately studied topic. Its main research findings indicate that higher $\mathrm{HL}$ is associated with younger respondents, females, respondents with at least secondary education, respondents earning more than 3.600 HRK per month and respondents who have better understanding in taking medicaments. Also, findings indicate that the level of $\mathrm{HL}$ could influence the cost-efficient use of medicaments which represent a significant burden to the public HC spending.

$\mathrm{HL}$ generates different economic effects on the healthcare system and influences the implementation of the public healthcare policies. For that reason, the research on the factors influencing the populations' $\mathrm{HL}$ directly contributes to better understand the economic effects of $\mathrm{HL}$. Future research should be focused on quantifying the costs and the savings of $\mathrm{HL}$ in Croatia. 


\section{REFERENCES}

Adams, R. J. et al. (2013). Functional health literacy mediates the relationship between socioeconomic status, perceptions and lifestyle behaviors related to cancer risk in an Australian population. Patient Educ Couns, 91(2): 206-12

Agencija za strukovno obrazovanje i obrazovanje odraslih (ASOO) (2011). Regionalna mreža lokalnih obrazovnih ustanova, Metode analize obrazovnih potreba za gospodarski razvoj: Primorsko-goranska županija, IPA Komponenta IV - Razvoj ljudskih resursa 2007-2009, Program Europske Unije za Hrvatsku, Accessed March 14, 2013. http://www.asoo.hr/UserDocslmages/projekti/mreza/County_HR/Primorsko-goranska.pdf

Baker, D.W. (2006). The Meaning and the Measure of Health Literacy.J Gen Intern Med, 21(8):878883.

Baker D.W. et al. (1998). Health literacy and the risk of hospital admission. J Gen Intern Med, 13(12): 791-798.

Baker D.W. et al. (1999). Development of a brief test to measure functional health literacy. Patient Educ Couns, 38(1): 33-42.

Baker D.W. et al. (2002). Functional health literacy and the risk of hospitalization among Medicare managed care enrollees. Am J Public Health, 92(8):1278-1283.

Baker D.W. et al. (2007). Health Literacy and Mortality Among Elderly Persons. Archives of Internal Medicine, 167(14):1503-1509,

Cerović, Lj., Dukić, N. and Horvat, T. (2012). The agency problem in healthcare and the importance of incentives. Knowledge and Business Challenges of Globalisation in 2012, 61-68

Croatian institute for health insurance (HZZO) (2013). Izvješće o poslovanju Hrvatskog zavoda za zdravstveno osiguranje za 2012. godinu", accessed April 12, 2013, http://www.hzzo-net. hr/dload/publikacije/lzvjesce_hz_1_12_2012.pdf

Eichler, K., Wieser, S., Brügger, U. (2009). The costs of limited health literacy: a systematic review, Int J Public Health, 54(5): 313-324.

Friedland, R. (1998). Understanding health literacy: new estimates of the high costs of inadequate health literacy, Proceedings of Pfizer Conference "Promoting Health Literacy: A Call to Action." October 7-8, 1998, Washington, DC: Pfizer Inc.

Friedland R. (2002). What Did the Doctor Mean? Estimating the Direct Health Costs of Low Functional Literacy. Working Paper.

Fuchs, V.R. (2000). The future of health economics. Journal of Health Economics 19: 141-57.

Gazmararian, J.A. et al. (1999). Health literacy among Medicare enrollees in a managed care organization. JAMA, 281(6): 545-551.

Grossman, M. (2000). The Human Capital Model of the Demand for Health, Handbook of Health Economics, Newhouse, Amsterdam

HLS - EU consortium (2012). Comparative report of health literacy in eight EU member states. The European health literacy survey HLS-EU, Accessed March 10, 2013. http://www.healthliteracy.eu 
Howard D.H., Gazmararian J., Parker R.M. (2005). The impact of low health literacy on the medical costs of Medicare managed care enrollees. Am J Med, 118(4): 371-377.

Hurley, J.E. (2000). An overview of the normative economics of the health sector, Handbook of Health Economics, Elsevier, edition 1, Vol. 1, chapter 2, 55-118.

Jensen, M.C. and Meckling, W.H. (1976). Theory of the firm: Managerial behavior, agency costs and ownership structure, Journal of Financial Economics, 3(4): 305-360.

Kirsch I. et al. (1993). Adult Literacy in America: A First Look at the Results of the National Adult Literacy Survey. Washington, DC: National Center for Education, US Dept of Education

Kutner M. A et al. (2005). National Assessment of Adult Literacy: First Look at the Literacy of America's Adults in the 21st Century. Washington, DC: National Center for Education Statistics, US Dept of Education

Lee, S.Y., Arozullah, A.M. and Cho Y.I. (2004). Health literacy, social support, and health: a research agenda, Social Science \& Medicine 58(7): 1309-1321.

McCormack, L. et al. (2010). Measuring Health Literacy: A Pilot Study of a New Skills-Based Instrument, Journal of Health Communication: International Perspectives, 15:S2,51-71.

Mirowsky J., Ross, C.E. (1998). Education, personal control, lifestyle, and health: a human capital hypothesis. Res Aging, 20(4): 415-449.

Nielsen-Bohlman L, Panzer A, Kindig D. (2004). Health Literacy: A Prescription to End Confusion. National Academy Press, Washington, D.C.

Nutbeam, D. (2000). Health literacy as public health goal: a challenge for contemporary health education and communication strategies into the 21st century. Health Promotion International, 15(3): 259-267.

Nutbeam, D. and Kickbusch, I. (2000). Advancing health literacy: A global challenge for the 21st century. Health Promotion International, 15(3), 183-184.

Pelletier, K. R. et al. (2009) Health and Medical Economics Applied to Integrative Medicine, The Journal of Science and Healing, 6(2): 86-99.

Pignone, M. et al. (2005) Interventions to Improve Health Outcomes for Patients with Low Literacy. Journal of General Internal Medicine 20(2): 185-192,

Ross, C.E., Mirowsky, J. (1999). Refining the association between education and health: the effects of quantity, credential, and selectivity. Demography, 36(4): 445-460.

Safeer, R.S. and Keenan, J. (2005). Health Literacy: The Gap Between Physicians and Patients, American Family Physician, 72(3): 463-468.

Schillinger, D. et al. (2002). Association of Health Literacy With Diabetes Outcomes. JAMA, 288(4): 475-482.

Simonds, S. (1974). Health Education as Social Policy, Health Education Monograph 2 Baltimore: Johns Hopkins University, 1-25. (In Perker, R.M., Ratzan, S.C. and Lurie, N. (2003). Health Literacy: A Policy Challenge For Advancing High-Quality Health Care, Health Affairs, 22(4): 147-153.) 
Suhrcke, M., Nugent, R. A., Stuckler, D., and Rocco, L. (2006). Chronic Disease: An Economic Perspective (Annex). London: The Oxford Health Alliance, Accessed September, 26, 2012. www.oxha.org/initiatives/economics

Sudore, R.L. et al. (2006). Limited Literacy in Older People and Disparities in Health and Healthcare Access, J Am Geriatr Soc, 54(5): 770-776.

US Department of Health and Human Services (2000). Healthy People 2010: Understanding and improving health and objectives for improving health. U.S. Department of Health and Human Services, Washington, D.C.

Vernon J.A. et al. (2007). Low Health Literacy: Implications for National Health Policy. University of Connecticut. National Bureau of Economic Research, Storrs, CT

Weiss, B.D. (2003). Health Literacy: A Manual for Clinicians. American Medical Association and American Medical Association Foundation

Weiss, B.D. (2007). Health literacy and patient safety: Help patients understand, Manual for clinicians, American Medical Association Foundation and American Medical Association.

Weiss, B.D. and Palmer, R. (2004). Relationship between health care costs and very low literacy skills in a medically needy and indigent Medicaid population. J Am Board Fam Pract,17(1): 44-47.

Weiss, B.D., Reed, R.L. and Kligman, E.W. (1995). Literacy skills and communication methods of low-income older persons. Patient Educ Couns, 25(2): 109-119.

Williams, M.V. et. al. (2002). The Role of Health Literacy in Patient-Physician Communication. FamilyMedicine, 34(5): 383-9.

Zahnd, W.E., Scaife, S.L., Francis, M.L. (2009): Health literacy skills in rural and urban populations, Am J Health Behav, 33(5): 550-557.

Zweifel, P., Breyer, F., and Kifmann, M. (1997). Health Economics. 2nd Ed. Heidelberg: Springer. 